\title{
Current Approach to the Prognostic Parameters of Testicular Germ Cell Tumors Accompanied by Our Cases
}

\author{
Testiküler Germ Hücreli Tümörlerin Prognostik Parametrelerine Olgularımız Eşliğinde Güncel \\ Yaklaşım
}

\author{
Ganime ÇOBAN ${ }^{1}$ \\ (D) 0000-0002-5779-6797 \\ Pelin YILDIZ ${ }^{1}$ \\ (D) 0000-0002-7709-7264 \\ Zeynep SEZAL ${ }^{1}$ \\ (10) 0000-0002-0112-0229 \\ Adila ADILLI ${ }^{1}$ \\ (D) 0000-0002-2743-930X \\ Mehmet BEŞİROĞLU ${ }^{2}$ \\ (D) 0000-0002-1171-8320 \\ Muzaffer AKÇAY ${ }^{3}$ \\ (D) 0000-0001-6716-3830 \\ Zuhal GUCIN ${ }^{1}$ \\ (D) 0000-0001-5330-2158
}

\begin{abstract}
${ }^{1}$ Bezmialem Vakif University Faculty of Medicine Department of Pathology, İstanbul, Turkey
\end{abstract}

${ }^{2}$ Bezmialem Vakif University Faculty of Medicine Department of Oncology, İstanbul, Turkey

${ }^{3}$ Bezmialem Vakif University Faculty of Medicine Department of Urology, İstanbul, Turkey

\section{Corresponding Author Sorumlu Yazar \\ Ganime ÇOBAN \\ drgcoban@hotmail.com}

Received / Geliş Tarihi : 28.04.2020 Accepted / Kabul Tarihi : 07.07.2020 Available Online /

Çevrimiçi Yayın Tarihi : 25.08.2020

\begin{abstract}
Aim: Testicular germ cell tumors (TGCT) are solid neoplasms common in young adult men and an important cause of cancer-related deaths during this period. Revisions in histopathological classification and staging affect prognosis and treatment. The aim of this study was to analyze our TGCT cases, to review prognostic parameters, and their relationship between germ cell neoplasia in situ (GCNIS), intratubular and intertubular tumors.

Material and Methods: In this study, Hematoxylin\&Eosin-stained sections of 77 TGCTs were re-evaluated. The presence of GCNIS, intratubular and intertubular germ cell tumors were recorded. Histopathological classification and staging were revised based on the changes in the 8th edition of American Joint Committee on Cancer (AJCC).

Results: The majority of the patients were diagnosed as seminoma $(n=42)$, followed by mixed germ cell tumors $(n=33)$ and spermatocytic tumors $(n=2)$. Rete testis invasion in 30 cases, epididymal invasion in 6 cases, hilar soft tissue invasion in 10 cases, tunica vaginalis invasion in 1 case, spermatic cord invasion in 4 cases, and lymphovascular invasion in 22 cases were detected. Intertubular seminoma in 25 cases, intratubular carcinoma in 16 cases, and GCNIS in 73 cases were detected.

Conclusion: The major criteria to determine treatment choices are histopathological diagnosis, pathological tumor stage, serum tumor markers and presence of metastasis. According to AJCC 8th edition, addition of hilar soft tissue invasion to staging has increased the number of our pT2 cases. Moreover, assuming discontinuous tumor invasion of spermatic cord by vascular invasion as pM1 has also increased the number of metastatic testis tumors. Keywords: Intratubular; intertubular; seminoma; mixed germ cell tumor.
\end{abstract}

\section{öz}

Amaç: Testiküler germ hücreli tümörler (TGHT), genç yetişkin erkeklerde sık görülen ve bu dönemdeki kanser ilişkili ölümlerin önemli bir sebebi olan solid neoplazmlardır. Histopatolojik sınıflandırma ve evrelemedeki değişiklikler, prognoz ve tedaviyi etkilemektedir. Bu çalışmanın amacı, TGHT tanısı almış olguların analizini yapmak, prognostik parametreleri ve bu parametrelerin insitu germ hücreli neoplazi (IGHN), intratubuler ve intertubuler tümörlerin varlığı ile ilişkilerini gözden geçirmektir.

Gereç ve Yöntemler: Bu çalışmada TGHT tanısı almış 77 olgunun Hematoksilen\&Eozin boyalı preparatları yeniden değerlendirildi. İGHN, intratubuler ve intertubuler germ hücreli tümör varlığı kaydedildi. Amerikan Birleşik Kanser Komitesi (American Joint Committee on Cancer, AJCC) 8. basımındaki değişiklikler temel alınarak yeniden histopatolojik sınıflama ve evreleme yapildi.

Bulgular: Olguların büyük çoğunluğu $(\mathrm{n}=42)$ seminom tanısı aldı, bunu mikst germ hücreli tümör $(n=33)$ ve spermatositik tümör $(n=2)$ izledi. Olguların 30'unda rete testis invazyonu, 6'sında epididim invazyonu, 10'unda hiler yumuşak doku invazyonu, 1 'inde tunika vaginalis invazyonu, 4'ünde spermatik kord invazyonu ve 22'sinde ise lenfovasküler invazyon görüldü. İntertubuler seminom 25, intratubuler karsinom 16, İGHN ise 73 olguda saptand1.

Sonuç: Histopatolojik tanı, patolojik tümör evresi, serum tümör belirteçleri ve metastaz olup olmaması tedaviyi belirleyen başlıca kriterlerdir. AJCC 8. basıma göre, hiler yumuşak dokuya invazyonun evrelemeye eklenmesi ile pT2 olgularımız arttı. Ayrıca, spermatik kord içerisinde devamlılık göstermeksizin damar trombüsünden yumuşak doku invazyonun pM1 olarak kabul edilmesi de metastatik testis tümörlerinin sayısını artırmıștır.

Anahtar kelimeler: İntratubuler; intertubuler; seminoma; mikst germ hücreli tümör. 


\section{INTRODUCTION}

Testicular germ cell tumors (TGCT), which make up about $98 \%$ of all testicular neoplasms, are the most common solid neoplasms in young adult men aged between 15-45 years $(1,2)$. Genetic and environmental factors play an important role in the etiology. The World Health Organization (WHO) divided TGCTs into two subgroups as germ cell neoplasia in situ (GCNIS)-derived tumors and non-GCNIS-derived tumors (3). Clinical behavior and treatment methods of the tumors are effective in this differentiation (Figure 1). TGCTs are also divided into two groups as seminoma and non-seminomatous tumors (NST) according to their histological features (4). Changes in the pathological staging of $\mathrm{T} 1$ and $\mathrm{T} 2$ tumors were made in the 8th edition of the American Joint Committee on Cancer (AJCC), and hilar soft tissue invasion and epididymal invasion were accepted as pT2. Additionally involvement of the spermatic cord soft tissue via a vascular thrombus without continuous path is better to be classified as a metastatic deposit, pM1 (5). Approximately two-thirds of the patients are in stage 1 at the time of diagnosis. Although TGCTs are malignant, they respond well to most treatments. They metastasize especially to retroperitoneal lymph node, lung, liver, bone and central nervous system (6).

The aim of this study was to analyze the cases diagnosed with TGCT in our hospital, to review the prognostic parameters, to detect GCNIS, intratubular and intertubular tumors and changes of staging of the tumors.

\section{MATERIAL AND METHODS}

Ethics committee approval was received for this study from the ethics committee of Bezmialem Vakif University (03.12.2019 and 22/411). The cases diagnosed with TGCT from the specimens of orchiectomy performed in our center between January 2012 and June 2019 were included in the study. Non-germ cell tumors were excluded. Hematoxylin\&Eosin (HE)-stained sections of the cases were re-evaluated. Histopathological diagnosis of the tumors and prognostic parameters including tumor diameter, tumor histology, rete testis, tunica vaginalis, hilar soft tissue and spermatic cord involvement and lymphovascular invasion were re-examined considering new classification and staging systems $(4,5)$. The presence of GCNIS, intratubular and intertubular germ cell tumors was recorded. Clinical findings and demographic data of the cases were also presented.

\section{Statistical Analysis}

Statistical evaluation was calculated with Microsoft Office 2010 Excel programme. Mean, standard deviation, median, min-max, frequency and percentage values were given as descriptive statistics.

\section{RESULTS}

Between January 2012 and June 2019, there were 77 cases diagnosed with germ cell tumors in our department. The mean age was $35.7 \pm 10.2$ (range, 17-64) years. The most common symptom was painless swelling in the testis. The laterality was; on the left testis in $43(55.8 \%)$ and in the right testis in $34(44.2 \%)$ of the cases. The mean diameter of the tumors was $4.3 \pm 1.9$ (range, $0.4-12$ ) cm. Forty two $(54.5 \%)$ of the cases had seminoma, $33(42.9 \%)$ had mixed germ cell tumors (MGCTs), and 2 (2.6\%) had spermatocytic tumors. GCNIS was observed in 73 (94.8\%) of the cases, while it was not observed in $4(5.2 \%)$ of the cases. There were no intratubular germ cell tumors in 61 (79.2\%) cases, while they were present in 16 (20.8\%) of the cases. One of these cases had intratubular embryonal carcinoma and the others had intratubular seminoma. Intertubular germ cell tumor was not observed in 52 $(67.5 \%)$ of the cases, while it was observed in 25 (32.5\%) of the cases (Figure 2). The stage of tumors was as follow: $51(66.2 \%)$ patients of T1, $23(29.9 \%)$ patients of T2, 2 (2.6\%) patients of $\mathrm{T} 3$, and $1(1.3 \%)$ patient of $\mathrm{T} 4$ was recorded. Thirty $(39.0 \%)$ of the cases had rete testis involvement. Pagetoid spread was observed in 4 cases with rete testis involvement, and two of them also had stromal invasion (Figure 3). Lymphovascular invasion (LVI) was detected in $22(28.6 \%)$ of the cases. Two of them had LVI in the spermatic cord. Epididymal invasion was detected in $6(7.8 \%)$ cases, hilar soft tissue invasion in $10(13.0 \%)$ cases, tunica vaginalis invasion in $1(1.3 \%)$ case, spermatic

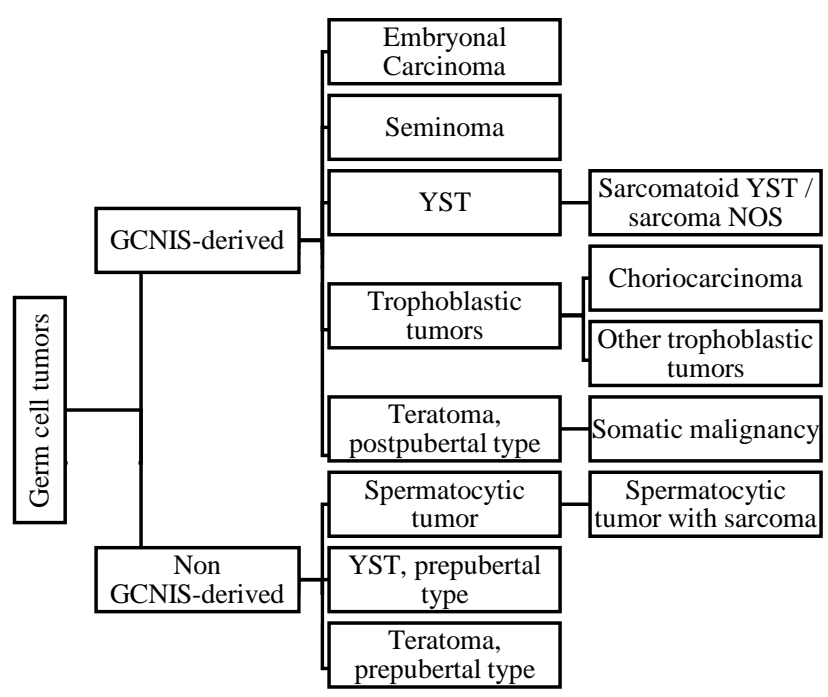

Figure 1. Classification of germ cell tumors (4). GCNIS: Germ cell neoplasia in situ, YST: Yolk Sac Tumor, NOS: Not Otherwise Specified

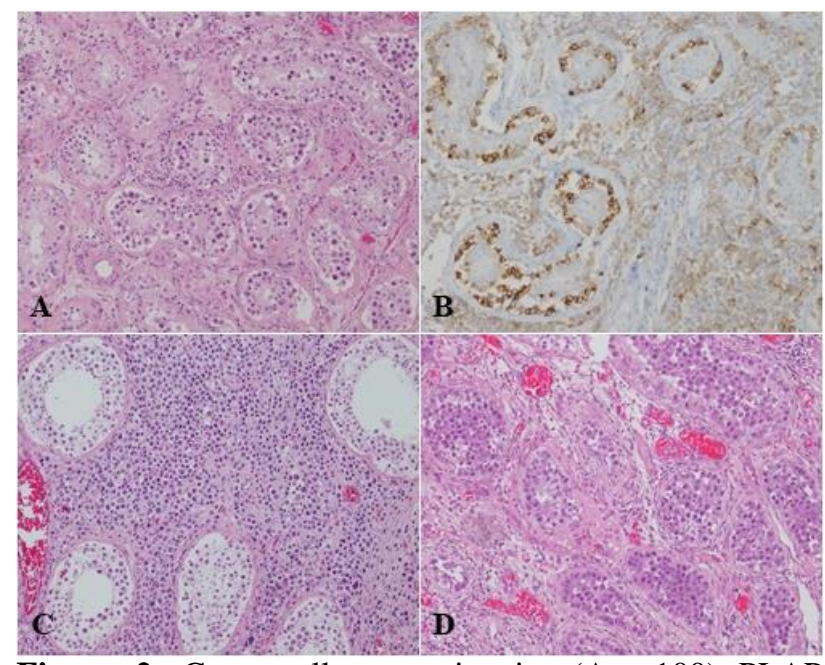

Figure 2. Germ cell tumor in situ (A, x100) PLAP immunohistochemistry with positive staining of germ cell tumor in situ (B, x100), intertubular and intratubular seminoma (C,D, x100). 
cord invasion in $4(5.2 \%)$ cases and scrotal invasion in 1 $(1.3 \%)$ case (Table 1$)$. Spermatic cord metastasis was detected in only one case. Retroperitoneal lymph node (RPLN) involvement was present in 19 cases. The mean follow up was $28.0 \pm 22.9$ (range, 1-91) months. Two cases (2.6\%) had lung metastasis, two cases $(2.6 \%)$ had liver metastasis, and one case $(1.3 \%)$ had central nervous system metastasis. The case with spermatic cord metastasis was followed for 38 months, and no other metastasis focus was observed. Intertubular seminoma was detected in 3 of 22 metastatic cases.

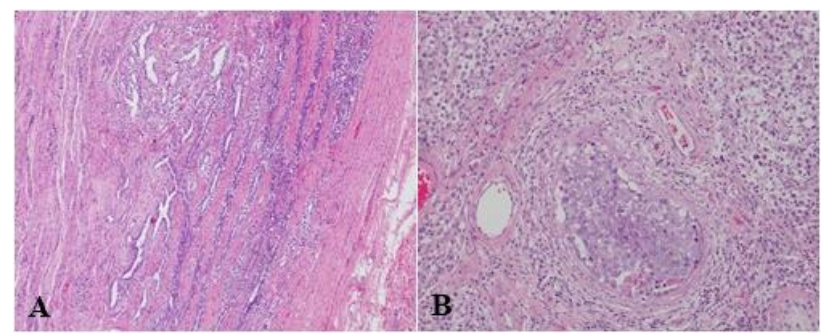

Figure 3. Rete testis stromal invasion and pagetoid spread (A, x40), lymphovascular invasion in the hilar soft tissue $(\mathrm{B}, \mathrm{x} 100)$

Table 1. Histopathological diagnosis and pathological tumor stages of the cases

\begin{tabular}{|c|c|c|c|}
\hline & Seminoma $(n=42)$ & MGCT $(n=33)$ & Spermatocytic Tumor $(n=2)$ \\
\hline Age (years), mean $\pm \mathrm{SD}$ (min-max) & $38.0 \pm 9.8(21-64)$ & $31.7 \pm 8.1(17-52)$ & $57.0 \pm 4.0(53-61)$ \\
\hline Diameter $(\mathbf{c m})$, mean \pm SD (min-max) & $3.9 \pm 2.0(0.4-12)$ & $4.6 \pm 1.5(2.5-9.2)$ & $6.5 \pm 1.5(5-8)$ \\
\hline \multicolumn{4}{|l|}{ Localization, n (\%) } \\
\hline Right & $21(50.0 \%)$ & $12(36.4 \%)$ & $1(50.0 \%)$ \\
\hline Left & $21(50.0 \%)$ & $21(63.6 \%)$ & $1(50.0 \%)$ \\
\hline GCNIS, n (\%) & $41(97.6 \%)$ & $32(97.0 \%)$ & $0(0.0 \%)$ \\
\hline Intertubular seminoma, n (\%) & $20(47.6 \%)$ & $5(15.2 \%)$ & $0(0.0 \%)$ \\
\hline Intratubular seminoma, n (\%) & $8(19.1 \%)$ & $7(21.2 \%)$ & $0(0.0 \%)$ \\
\hline Intratubular embryonal carcinoma, n (\%) & $0(0.0 \%)$ & $1(3.0 \%)$ & $0(0.0 \%)$ \\
\hline \multicolumn{4}{|l|}{ Pathological Stage, n (\%) } \\
\hline Rete testis invasion & $12(28.6 \%)$ & $18(54.5 \%)$ & $0(0.0 \%)$ \\
\hline Hilar soft tissue invasion & $6(14.3 \%)$ & $4(12.1 \%)$ & $0(0.0 \%)$ \\
\hline Epididymal invasion & $3(7.1 \%)$ & $3(9.1 \%)$ & $0(0.0 \%)$ \\
\hline Spermatic cord invasion & $0(0.0 \%)$ & $4(12.1 \%)$ & $0(0.0 \%)$ \\
\hline Tunica vaginalis invasion & $1(2.4 \%)$ & $0(0.0 \%)$ & $0(0.0 \%)$ \\
\hline Lymphovascular invasion & $7(16.7 \%)$ & $15(45.5 \%)$ & $0(0.0 \%)$ \\
\hline
\end{tabular}

MGCT: Mixed Germ Cell Tumor, GCNIS: Germ cell neoplasia in situ

\section{DISCUSSION}

GCNIS-derived tumors are seen in the postpubertal period between the ages of 18-45 years, on average, while nonGCNIS-derived tumors are usually seen in the prepubertal period. In our study, the most common tumors were GCNIS-derived tumors, and there were 4 non-GCNISderived germ cell tumors.

TGCTs are also divided into two groups as seminoma and NST, considering prognosis and different treatment options. Seminoma is seen at the rate of $55 \%$, while NST is seen at the rate of $45 \%(7,8)$. In this study, seminoma was detected at the rate of $54.5 \%$, spermatocytic tumor was observed at the rate of $2.6 \%$, and MGCT was observed at the rate of $42.9 \%$. Embryonal carcinoma and teratoma were the most common MGCTs. Seminomas may sometimes be accompanied by syncytiotrophoblasts, which should not be considered as MGCTs. The term "unclassified intratubular germ cell neoplasia", which were precursor lesions of TGCTs was replaced by the term "GCNIS" in the 2016 WHO classification. GCNISs are the precursor lesions of invasive germ cell tumors, and $70 \%$ of these lesions develop invasive cancer 7 years after diagnosis (9). GCNISs are seen $72-98 \%$ of peritumoral area, whereas they can be detected incidentally in $0.4-0.8 \%$ of the patients without an invasive tumor (10). GCNIS was seen in $94.8 \%$ of our cases, which was consistent with the rates reported in the literature. OCT3 / 4 and placental alkaline phosphatase (PLAP) are most commonly used in detecting GCNIS, although numerous immunohistochemical markers have been investigated (11) in addition to HE sections. Among non-invasive germ cell neoplasms, there are specific forms of intratubular germ cell neoplasia called intratubular seminoma (ITS) or intratubular embryonal carcinoma (ITEC) (3). Intratubular carcinoma was observed in $20.8 \%$ of our cases. All of these cases had invasive tumors. ITS is located in a separate focal area, between the seminiferous tubules next to the mass-forming seminoma area, without disturbing the pattern of the tubules. This tumor, also called microinvasive germ cell tumor, can be detected in cases operated due to cryptorchidism (12). The presence of concomitant distant metastases at the time of diagnosis in two ITS cases of Henley (13) suggests that these in situ lesions may be associated with prognosis.

Histopathological diagnosis, pathological tumor stage, serum tumor markers and the presence of metastasis are the main criteria that determine treatment. Both seminoma and NSGCT have similar criteria for pathological staging. However, unlike NSGCT, pT1 is subclassified as T1a and $\mathrm{T} 1 \mathrm{~b}$ according to tumor diameter in seminoma (5). Tumor diameter is known to be important in adjuvant RT or carboplatin-based therapy. There is no criterion for diameter in other germ cell tumors. Tumor stage of seminomas were reported as following: pT1a (28.6\%), 
pT1b (71.4\%). Rete testis invasion is clinically important, although it is not involved in pathological staging. The tumor should be screened carefully with serial sections, since a tumor showing pagetoid spread throughout the rete testis may also show stromal invasion. Yilmaz et al. (14) stated that the tumor showing rete testis stromal invasion had a direct relationship with advanced clinical stage, but there was no relationship between pagetoid spread and clinical stage. Rete testis invasion increases the risk of recurrence with increasing tumor diameter, especially in seminomas (15). In addition, Lobo et al. (16) found a relationship between rete testis invasion and LVI and that rete testis invasion increased in seminomas over $3 \mathrm{~cm}$. Rete testis stromal invasion was observed in $39 \%$ of our cases, and two of them also had pagetoid spread. There were also two cases showing only pagetoid spread. LVI was seen in $46.7 \%$ of the cases with rete testis invasion. There were 33 cases with seminoma over $3 \mathrm{~cm}, 33.3 \%$ of them had rete testis invasion, which was consistent with the literature reported by Lobo et al. (16).

Pathological tumor stage is T2 in the presence of tunica vaginalis, LVI, epididymal invasion and hilar soft tissue invasion (17). Hilar soft tissue invasion is most common localization for extratesticular spread in both seminoma and NSGCT $(1,18)$. Hilar soft tissue invasion rates of our cases $(13.0 \%)$ was consistent with the literature. Interestingly, hilar soft tissue invasion is staged as T2, while rete testis invasion, which is the border in transition of tumor to this area and found to be associated with high metastasis especially in seminomas, and is not involved in pathological staging. LVI can be found in the intraparenchymal area, tunica and spermatic cord, and it is considered as pT2 (19). LVI is effective in recurrence. Divrik et al. (20) detected relapse in $75.5 \%$ of those with LVI and $17.9 \%$ of those without LVI in 211 Stage 1 NSGCT cases. McCleskey et al. (21) showed that the first one had a more advanced clinical stage in their study comparing LVI seen in NSGCTs without spermatic cord invasion with LVI identified in the testis. They did not detect this relationship in seminomas. Gordetsky et al. (22) found that LVI observed in the spermatic cord and T3 were in similar clinical stages in NSGCTs, and there was no difference in terms of recurrence rates. One of our cases had LVI in the spermatic cord and liver metastasis.

Another noteworthy point is whether spermatic cord invasion is continuous or not. Continuous spermatic cord stromal invasion with or without LVI is considered as pT3, while spermatic cord stromal invasion, which is discontinuous along the spermatic cord, with or without LVI is considered as pM1 $(17,19)$. This may require a complete sampling of the spermatic cord by numbering from the hilar soft tissue to the surgical margin of the spermatic cord in testicular tumors.

In addition to histopathological diagnosis and pathological staging, the presence of microlithiasis, atrophy and sertoli cell nodule in the non-tumor testicular tissue are other risk factors that should be stated in the report (23). In our reports, we record the findings such as microlithiasis, atrophy and sertoli cell nodules in non-tumoral testicle tissue. TGCTs may be accompanied by lymphoplasmacytic inflammation and granulomas. Sharma et al. (24) found that CD66b-positive neutrophils were an independent prognostic factor in their study.
Cisplatin-based chemotherapy and surgery provide high cure rates, while resistance to treatment and poor prognosis were seen at the rate of $15 \%$ in germ cell tumors. Martinelli et al. (25) found that CALCA and MGMT were associated with poor prognosis, and CALCA methylation was associated with refractory disease in germ cell tumors. While microsatellite analysis of mismatch repair genes is not associated with clinical course, epididymal invasion and EGFR expression are associated with recurrence in stage 1 tumors (26). Aurora-B, serine-threonine kinases, GPR30 and HMGAs are the new molecules that can be used in targeted therapy in resistant cases (27).

\section{CONCLUSION}

In this study, we discussed the important criteria in the staging of testicular germ cell tumors, accompanied by our cases. Both histopathological diagnosis rates and pathological stages are consistent with the literature. We observed that the number of pT2 tumors increased with the addition of hilar soft tissue invasion to the staging. Additionally a case with spermatic cord invasion was previously regarded as pT3 was carried to pM1 group. We think that it is necessary to examine the whole cord by coding in macroscopic evaluation if possible, since spermatic cord involvement may be associated with $\mathrm{T} 3$ or M1. The number of spermatic cord metastasis was detected in only one case. More studies with large number of patients would be helpful for making comparison with prognostic parameters.

\section{REFERENCES}

1. Landero-Huerta DA, Vigueras-Villasenor RM, Yokoyama-Rebollar E, Arechaga-Ocampo E, RojasCastaneda JC, Jimenez-Trejo F, et al. Epigenetic and risk factors of testicular germ cell tumors: a brief review. Front Biosci (Landmark Ed). 2017;22 (7):1073-98.

2. Greene MH, Kratz CP, Mai PL, Mueller C, Peters JA, Bratslavsky G, et al. Familial testicular germ cell tumors in adults: 2010 summary of genetic risk factors and clinical phenotype. Endocr Relat Cancer. 2010;17(2):R109-21.

3. Ulbright TM. Recently described and clinically important entities in testis tumors: a selective review of changes incorporated into the 2016 classification of the World Health Organization. Arch Pathol Lab Med. 2019;143 (6):711-21.

4. Moch H, Humphrey PA, Ulbright TM, Reuter VE. WHO classification of tumours of the urinary system and male genital organs, 4th ed. Geneva, Switzerland: WHO; 2016.

5. Amin MB, Edge S, Greene F, Byrd DR, Brookland RK, Washington MK, et al. AJCC cancer staging manual, 8th ed. Switzerland: Springer; 2017.

6. Johnson K, Brunet B. Brain metastases as presenting feature in 'burned out' testicular germ cell tumor. Cureus. 2016;8(4):e551.

7. Winter C, Albers P. Testicular germ cell tumors: pathogenesis, diagnosis and treatment. Nat Rev Endocrinol. 2011;7(1):43-53.

8. Sheikine Y, Genega E, Melamed J, Lee P, Reuter VE, Ye H. Molecular genetics of testicular germ cell tumours. Am J Cancer Res. 2012;2(2):153-67. 
9. Hoei-Hansen CE, Rajpert-De Meyts E, Daugaard G, Skakkebaek NE. Carcinoma in situ testis, the progenitor of testicular germ cell tumours: a clinical review. Ann Oncol. 2005;16(6):863-8.

10. Al-Hussain T, Bakshi N, Akhtar M. Intratubular germ cell neoplasia of the testis: a brief review. Adv Anat Pathol. 2015;22(3):202-12.

11. Cierna Z, Mego M, Jurisica I, Machalekova K, Chovanec M, Miskovska V, et al. Fibrillin-1 (FBN-1) a new marker of germ cell neoplasia in situ. BMC Cancer. 2016;16(1):597.

12. Chu YH, Huang W, Hu R. Exclusively intertubular seminoma arising in undescended testes: Report of two cases. Hum Pathol Case Reports. 2018;11:15-8.

13. Henley JD, Young RH, Wade CL, Ulbright TM. Seminoma with exclusive intertubular growth: a report of 12 clinically and grossly inconspicuous tumors. Am J Surg Pathol. 2004;28 (9):1163-8.

14. Yilmaz A, Cheng T, Zhang J, Trpkov K. Testicular hilum and vascular invasion predict advanced clinical stage in nonsminomatous germ cell tumors. Mod Pathol. 2013;26(4):579-86.

15. Groll RJ, Warde P, Jewett MAS. A comprehensive systematic review of testicular germ cell tumor surveillance. Crit Rev Oncol Hematol. 2007;64(3):182-97.

16. Lobo J, Costa AL, Vilela-Sagueiro B, Rodrigues Â, Guimarães R, Cantante $\mathrm{M}$, et al. Testicular germ cell tumors: revisiting a series in light of the new WHO classification and AJCC staging systems, focusing on challenges for pathologists. Hum Pathol. 2018;82:11324.

17. Verrill C, Yilmaz A, Srigley JR, Amin MB, Compérat E, Egevad L, et al. Reporting and staging of testicular germ cell tumors: The International Society of Urological Pathology (ISUP) testicular cancer consultation conference recommendations. Am J Surg Pathol. 2017;41(6):e22-32.

18. Yilmaz A, Trpkov K. Hilar invasion in testicular germ cell tumors: a potential understaging pitfall. Mod Pathol. 2015;28(Supll):269A.
19. Brimo F, Srigley JR, Ryan CJ, et al. Chapter 59: Testis. In: Amin MB, Edge S, Greene F, Byrd DR, Brookland RK, Washington MK, et al. eds. AJCC cancer staging manual, 8th ed. Switzerland: Springer; 2017. p.727-35.

20. Divrik RT, Akdoğan B, Ozen H, Zorlu F. Outcomes of surveillance protocol of clinical stage I nonseminomatous germ cell tumors-is shift to risk adapted policy justified? J Urol. 2006;176(4 Pt 1):1424-9.

21. McCleskey BC, Epstein JI, Albany C, HashemiSadraei N, Idrees MT, Jorns JM, et al. The significance of lymphovascular invasion of the spermatic cord in the absence of cord soft tissue invasion. Arch Pathol Lab Med. 2017;141(6):824-9.

22. Gordetsky J, Sanfrancesco J, Epstein JI, Trevino K, Xu $\mathrm{H}$, Osunkoya A, et al. Do nonseminomatous germ cell tumors of the testis with lymphovascular invasion of the spermatic cord merit staging as pT3? Am J Surg Pathol. 2017;41(10):1397-402.

23. Tan IB, Ang KK, Ching BC, Mohan C, Toh CK, Tan MH. Testicular microlithiasis predicts concurrent testicular germ cell tumors and intratubular germ cell neoplasia of unclassified type in adults: a meta-analysis and systematic review. Cancer. 2010;116(19):4520-32.

24. Sharma P, Dhillon J, Sexton WJ. Intratubular germ cell neoplasia of the testis, bilateral testicular cancer, and aberrant histologies. Urol Clin North Am. 2015;42(3):277-85.

25. Martinelli CMDS, Lengert AVH, Cárcano FM, Silva ECA, Brait M, Lopes LF, et al. MGMT and CALCA promoter methylation are associated with poor prognosis in testicular germ cell tumor patients. Oncotarget. 2017;8(31):50608-17.

26. Sanmamed MF, Esteban E, Uriol E, Zarate R, Capelan M, Muriel C, et al. Epidermal growth factor receptor and epididymis invasion as prognostic biomarkers in clinical stage I testicular germ cell tumours. J Transl Med. 2017;15(1):62

27. Chieffi P. An up-date on novel molecular targets in testicular germ cell tumors subtypes. Intractable Rare Dis Res. 2019;8(2):161-4. 